\title{
HOW DO U.S. STATE FIREARMS LAWS AFFECT FIREARMS MANUFACTURING LOCATION? AN EMPIRICAL INVESTIGATION, 1986-2010
}

Jurgen Brauer*, Daniel Montolio**, and Elisa Trujillo-Baute***

\section{ABSTRACT}

We exploit variations in U.S. state firearms laws to study their relation to the spatial distribution of more than 2,700 federally licensed manufacturers of firearms for the civilian and law enforcement markets across the country. Accounting for a variety of economic factors - such as cost, tax burden, and agglomeration effects - we find that states with relatively permissive, enduser friendly laws host more firearms manufacturing establishments than do states with relatively restrictive, end-user unfriendly laws. This supply side-oriented paper complements a literature that predominantly attends to the market's demand side. It thus opens up a new avenue to study the U.S. civilian firearms market.

JEL Classification Codes: K23, L10, L52, L64, H73

Key Words: United States, state firearms laws, firearms manufacturing.

* Jurgen Brauer <brauer.jurgen@gmail.com>. Corresponding author. Hull College of Business, Augusta University, Augusta, GA 30904, USA, and EBA Program, Faculty of Economics, Chulalongkorn University, Bangkok, Thailand.

** Daniel Montolio<montolio@ub.edu>. Faculty of Economics and Business and Barcelona Institute of Economics, University of Barcelona, Barcelona, Spain.

*** Elisa Trujillo-Baute <elisamtrujillob@gmail.com>. University of Warwick, Coventry, UK, and Barcelona Institute of Economics, Barcelona, Spain. 


\section{HOW DO U.S. STATE FIREARMS LAWS AFFECT FIREARMS MANUFACTURING LOCATION? AN EMPIRICAL INVESTIGATION, 1986-2010}

\section{INTRODUCTION}

An extensive scholarly literature addresses demand-side aspects of the firearms market, both for the United States and elsewhere, and especially so in regard to illicit firearms trade and to selfdirected, accidental, or criminal firearms misuse. ${ }^{1}$ In contrast, there is little literature on - and hence little understanding of - the supply side of the market to address questions such as these: Who are the suppliers and how many are there? How much do they produce and at what cost? What is the product range and how much do manufacturers charge for their products? What is the industrial organization of the industry? How do federal and state (or national and provincial) laws and regulations influence firms' behavior and collective market outcomes? ${ }^{2}$

This paper studies how variations in U.S. state firearms laws affect the number of firearms manufacturing plants (or "establishments") across states. It thus opens up a supply-side avenue for the empirical investigation of de facto firearms policy as enshrined in state laws. In addition, and unlike a number of recent studies, ours is based on much more extensive - and unique panel data, covering the time period 1986 to $2010 .{ }^{3}$ Statistically controlling for factors such as

\footnotetext{
${ }^{1}$ Of the ample literature see, e.g., Cook and Ludwig (2000); Hemenway (2004); Cook and Goss (2014); Briggs and Tabarrok (2014); Taylor and Li (2015).

${ }^{2}$ From the 1960s and into the early 1980s, economic historians debated the role of firearms manufacturing within the American System of Manufacture, that is, the role of firearms production during the advent of mechanization and mass production with interchangeable parts in the 1800s. Industries that worked with metals and revolving parts such as agricultural implements (e.g., reapers), sewing machines, clock making, bicycles, locomotives, and firearms played a prominent role as precursors to the rise of industrialization (see, e.g., Habakkuk, 1962; Rosenberg, 1963; Howard, 1979; Smith Merritt, 1973; Hounshell, 1984). For more recent, industrial organization type of work, see Hall, et al. (2008) and, especially, Brauer (2013).

${ }^{3}$ Firearms policy: Other research examines aspects such as health and public safety of relatively lax or strict state firearms laws, e.g., Webster, Crifasi, and Vernick (2014). Recent studies: See, e.g., Fleegler, et al. (2013); Kahane (2013); Knight (2013); Lanza (2013); Depetris-Chauvin (2015).
} 
the size of state populations, labor force unionization rates, industrial wage rates, tax burdens, and the share of manufacturing in state economies, we test the hypothesis that U.S. states with firearms laws deemed favorable to firearms end-users host a larger number of firearms establishments than do those with less favorable laws. While this hypothesis may seem straightforward, it does not appear to have been tested statistically, separating out the effect of state firearms laws from other factors that might affect the number of firearms establishments for any given state and year. Our findings suggest that states with relatively lax firearms laws do host disproportionately large numbers of firearms establishments. However, we also find that the number of plants in a particular state and year is affected by a variety of factors, of which relevant law is but one. "Permissive" or "restrictive" law alone does not suffice to determine the number of firearms manufacturing establishments. ${ }^{4}$

The paper is motivated, in part, by a spate of announcements firearms manufacturers made in 2013 and 2014 to move their production lines out of the U.S. state of Connecticut, following a mass shooting there in December 2012 and which led to a discussion of whether to "strengthen" that state's firearms laws. ${ }^{5}$ Similar pronouncements - "If the law is tightened, we move" - have been made by manufacturing members of the industry in the wake of other mass shootings, prior to 2012. This paper assesses the implied threat, i.e., the relation between state firearms laws and firearms manufacturing location, with the data at hand (1986-2010) when we commenced the research. Since state firearms laws, in Connecticut as elsewhere, do not primarily regulate

\footnotetext{
${ }^{4}$ We do not estimate a tipping point beyond which "restrictive" law becomes "permissive" as the state firearms laws data we have assembled are not sufficiently unambiguous and fine-grained to justify such an effort. Note that statelevel data are too coarse to show meaningful clustering and hence preclude us from using spatial techniques that could be appropriate if one focused on county-level data as, for instance, McDougal, et al. (2014).

${ }^{5}$ The shooting occurred at an elementary school in Newtown, CT, and sparked a nationwide debate on federal and state firearms laws. For an overview of law changes that were proposed, see Krouse (2013). For journalistic accounts of mooted or actual state-to-state moves by firearms manufacturers, see Ghosh (2014) and Shooting Industry, the industry's main trade publication (January 2015, p. 47).
} 
firearms production but end-user access to and use of firearms, ${ }^{6}$ and since the firearms market is thoroughly national - there are federal but no state-level restrictions on firearms shipments from manufacturers to wholesale or retail outlets anywhere in the country - the main criterion for firearms manufacturing location should be idiosyncratic location preferences and economic cost, not state firearms laws directed at end-users. Thus, after accounting for cost, the threat to move, or any actual move, of firearms manufacturing from one state to another must have a behavioral component to it, reflecting a firm's preference to be located in one state rather than another. For example, given the long-standing political and cultural controversy in the country surrounding the ownership and use of firearms, manufacturers and their employees might feel more welcome in firearms-"friendly" states and or they might consider a state-to-state move as a form of protest, even as this may be costly from a business perspective. Since we include cost-relevant and other control variables in our empirical work, we can isolate their effect from the law-variables to capture this behavioral aspect. ${ }^{7}$

Regarding causality, state firearms laws are not passed randomly at random times. The relevant laws that are in force in any given year instead might be viewed as endogenous to previously evolved population preferences in regard to firearms access and end-use. Importantly,

\footnotetext{
${ }^{6}$ We will return to this point but already it may be indicated that it is extremely important to appreciate that there are no production-focused state firearms laws per se. State firearms laws are aimed at firearms access and end-use. In the case of Connecticut, for example, new restrictive state laws introduced in 2013 expressly do not restrict manufacturing, only end-use. Thus, even though use-limitations were imposed on so-called assault weapons, for example, the law also states that "[a]ny person, firm, or corporation engaged in the business of manufacturing assault weapons in Connecticut may manufacture or transport them for sale in state to exempt parties or out of state" (CGS § 53-202i, as amended by PA 13-3; our emphasis). Quoted from the Office of Legislative Research, Connecticut General Assembly, 29 May 2013, 2013-R-0241, "Weapons Banned as Assault Weapons" Appendix II (http://www.cga.ct.gov/2013/rpt/2013-R-0241.htm) [accessed 19 January 2015].

${ }^{7}$ As we explain later, the raw data on manufacturers cannot reliably identify firms newly established in any one state or year. In our empirical work, we track the annual stock of manufacturing establishments present in a state so that if company $X$ did move all or part of its manufacturing operations from state $Y$ in year $t$ to state $Z$ in year $t+l$, this movement will be captured in our establishment stock data.
} 
however, neither the content nor the timing of changes in state firearms laws is straightforward. Changing state firearms laws is an intensely contested activity, can take considerable time to implement, can enable and disable different aspects of the law at the same time, and often results in fairly minor net adjustments to the law (as was the case for the Connecticut shooting). In that sense, law is not all that reactive to or contemporaneous with on-the-ground events. Moreover, as already indicated in note 6, and as shown in more detail in Section II, state firearms laws overwhelmingly are consumer-oriented laws, not producer-oriented laws, and thus exogenous to establishment decisions, reflecting the overall firearms-related state "business climate" for firearms manufacturers. ${ }^{8}$ Section II discusses our unique datasets and presents the expected results for our main variables of interest. Section III discusses our estimation strategy and presents the actual estimations and results. Section IV discusses, interprets, and contextualizes the findings.

\section{DATA}

Apart from control variables, four main datasets are of relevance. To understand their possibilities and limitations, each needs careful description. We label the four datasets as (1) ATF/AFMER; (2) ATF/Laws; (3) B/L; and (4) V/H. The first of these concerns firearms production and location data; the other three concern data regarding state firearms laws. ${ }^{9}$

\section{Firearms Manufacturers (ATF/AFMER)}

The first dataset is compiled from print copies of the Annual Firearms Manufacturing and Export Report (AFMER), a publication of the Bureau of Alcohol, Tobacco, Firearms, and Explosives

\footnotetext{
${ }^{8}$ In Appendix B we show empirically that while state firearms laws do affect firearms demand, the laws' effect on demand does not spill over to the manufacturing establishment aspect of the supply-side of the market.

${ }^{9}$ In Appendix B, we describe a fifth dataset, the FBI's monthly National Instant Background Check System (NICS).
} 
(ATF). Under federal law, in the United States every manufacturer and importer of, and dealer in, firearms or other destructive devices must obtain a federal firearms license (FFL). This license is issued for the actual premise (or "establishment") of firearm manufacture or sale. For example, for Kahr Arms - a prominent pistol maker - the FFL is issued not for its corporate headquarters in New York state, but for its manufacturing sites in Massachusetts (in the town of Worcester, MA, under the licensee name Saeilo, Inc., which is Kahr's parent company) and in Minnesota (in the towns of Fridley, Minneapolis, and Pillager, under licensee Magnum Research, a division of Kahr Arms). Also by federal law, each U.S.-based manufacturer is required annually to report to the ATF the number of firearms released into commerce (direct sales, wholesale, or retail for domestic release or for export, but excluding military sales). ${ }^{10}$ Intermediary manufactures who sell to other manufacturers to finish or assemble firearms do not report to AFMER and therefore do not form part of our dataset. Further, licenses are valid for three years, but not every FFL manufacturer necessarily sells firearms in every year. Thus, the total number of FFLs is substantially different from the total number of FFLs required to report to AFMER.

At the time of the data collection, records were available for 1998 to 2012 in PDF format on the ATF's website. ${ }^{11}$ Because of limitations on other data, the research reported here extends through the year 2010 only. In addition, through a Freedom of Information Act (FOIA) request we obtained additional annual AFMER records reaching back to 1986 so that our manufacturing

\footnotetext{
10 "Released into commerce" does not necessarily equal "production" as production into inventory is not counted. In contrast, sales from inventory are counted. For example, if in 2009 manufacturer ABC produced 1,000 firearms, sold 900, and put the remaining 100 into inventory, it would report to the ATF 900 firearms "released into commerce." If $\mathrm{ABC}$ in 2010 then produced 1,500 firearms, but sold 1,600 (1,500 produced plus 100 from the prior year's inventory), ABC would report to the ATF unit sales of 1,600 for the year 2010.

${ }^{11}$ As of 2014, the ATF has made some datasets available in an electronic format. See https://www.atf.gov/resourcecenter/data-statistics (last accessed 5 February 2016).
} 
database includes all reporting firearms establishments for the calendar years 1986 to 2010. For each premise, we know the street address and the number of firearms produced for each type of firearm (pistol, revolver, rifle, shotgun, and miscellaneous firearms).

Certain problems arise in statistical work when using the AFT/AFMER data. As mentioned, the federal firearms license is issued for each premise. Thus, our database includes information on federal firearms licensees at 3,151 physical addresses. However, when a licensee changes its legal name during a given calendar year, say from Arms Mfg, Inc. to Arms Mfg, LLC, technically a new FFL is required. The same address is entered twice for that year, leading to double counting of establishments. Likewise, when Remington Arms and therefore its Ilion, NY, plant changed ownership, a new FFL was required for the new owners to operate the plant, even as the premise did not change. For the year in which ownership changed, there are then two entries in that year's AFMER, one under the old ownership and one under the new ownership. For well-known firearms manufacturers one can make corrections in the dataset if one is familiar with ownership changes. But for the vast majority of FFLs, ownership information is not available and judgments have to be made of whether or not to treat a specific street address as a genuinely new firearms establishment or as a continuing operation under a different licensee name.

In another example, a firm going by the licensee name Entreprise Arms Inc. (the unusual spelling is correct) has had three FFLs issued for three physical addresses, all in Irwindale, California, and all within a distance of 1.7 miles of each other. This appears to be a firm under continuous ownership, just changing to a different premise within the same part of town. What are three entries in the ATF/AFMER database should, for our purposes, be one. Similarly, from time to time FFLs need to be renewed. Some manufacturers let their license lapse, however. 
When reissued, it is issued with a new FFL number and entered in the AFT/AFMER record as a new premise even if the physical address is identical to one used in some prior year. Another quirk is that a firm may produce reportable firearms in one year, then not produce firearms for several years (but continue other metal-works fabrications, or produce only as a contract manufacturer), and then produce reportable firearms again, in effect acting like a peak-load producer when demand is high for instance. In a word, it is difficult to reliably identify genuinely new firearms establishments in the AFMER data. Our work therefore uses the annual stock of reporting firms as its dependent variable.

The issue of establishment double-counting can be dealt with, if somewhat imperfectly. Given our industry knowledge, we made adjustments where we could and ultimately retained 5,953 data points, corresponding to a total of 2,721 unique firearms manufacturing plants across the 25-year span of our data. Table 1 shows the record by state for selected years. For 1986, for instance, California shows 22 firearms plants. In 2010, there were 27. The state-by-state composition of firearms manufacturing premises definitely has changed over the years, and the research question simply asks how, apart from cost and other control variables, state firearms laws may have affected this changing composition.

\section{TABLE 1 ABOUT HERE}

\section{Regulatory variables}

\subsection{ATF/Laws}

The other three main datasets are codings of state firearms laws. The first of these comes from the ATF as well, and we refer to this dataset as ATF/Laws. From time to time, the Bureau issues a publication called ATF State Laws and Published Ordinances-Firearms (ATF Publication 5300.5). The 31st edition, for example, refers to 2010-2011 and consists of over 500 densely 
printed pages. The currency of the state laws and publications, however, varies. For Alabama, for example, the publication is current through the "End of [the] 2010 First Special Session," for California through to the end of the "2009 Regular and Extraordinary Session," for Indiana, through the end of the "2010 Second Regular Session," and so on. A check with the relevant personnel revealed that the ATF itself does not keep a full set of copies of past editions of Publication 5300.5. From various libraries we obtained full or partial copies of Publication 5300.5 for the publication years 1998 (21st ed.), 2000 (22nd ed.), 2001 (23rd ed.), 2003 (24th ed.), 2004 (25th ed.), 2005 (26th ed.), 2006 (27th ed.), 2007 (28th ed.), 2008 (29th ed.), 20092010 (30th ed.), and 2010-2011 (31st ed.). While the publications are continuous - the twentyfirst to the thirty-first editions - there are data gaps for 1998 and 2001 (no corresponding 1999 and 2002 editions were published for those data years). For the case of the 2001 data, the data was indirectly obtained and reconstructed for all states, given the consistency of the values of the relevant regulatory variables for 2000 and 2002. A similar procedure was applied to the 1998 data gap; however, in the latter case not all the information was recovered. Therefore, for the year 1998 some observations are missing. Consequently, we decided to perform two sets of estimations, one for the whole sample period (1997-2010) with some missing values, and another for a restricted sample (2000-2010) with all the information for the ATF/Laws regulatory variables.

Moreover, the ATF publishes only a selection of state laws and municipal ordinances and, as mentioned, in a number of cases we were able to locate only partial copies of the entire publication. In each case, however, we do have what the ATF refers to as the Ready Reference Table, a state-by-state summary of laws in regard to four specific themes: (1) Does the state impose a waiting period for prospective firearms purchasers (and, if so, for how long)? (2) Does 
the state require firearms manufacturers and/or dealers residing in their state to carry a state license in addition to the required federal license? (3) Does the state preempt subordinate municipalities within the state from issuing their own firearms ordinances? And (4) does the state impose limits on the interstate purchase and sale of firearms with immediately neighboring (contiguous) states?

For example, in the 2006 edition of ATF/Laws, the state of Connecticut is listed as having a 2-week-long waiting period for long guns (but not handguns); requires manufacturers and dealers of handguns (but not of long guns) to carry a state license in addition to the federal license; has no state laws in regard to preemption of municipal ordinances; and likewise has no provisions in regard to interstate commerce. As shown in Table 2, Panel A, we implement coding of these four state law variables in two ways: First, as zero-one binary variables indicating the absence or presence of a state law regarding a firearms purchase waiting period (ATF_waitperiod_1), preemption of local (i.e., municipal) regulation by state law (ATF_preemption), and whether there are state law restrictions on end-user commerce with immediately neighboring states $\left(A T F \_\right.$interstate $)$and, second, as count variables where we count the number of provisions in state law with respect to the variables purchase waiting period (ATF_waitperiod_2) and state licensing requirements for dealers or manufacturers (ATF_statelicense). For example, for purchase waiting period, we code either 0 or 1 or the number of hours (14 days, i.e., 336 hours, for Connecticut, for instance) and we code the number of state laws dealing with licensing (for the year 2005, two for Maryland, for instance, namely Public Safety Act Art. 5-106 and Art. 11105). (Note that Appendix Table A1 contains a more detailed version of Table 2.)

\section{TABLE 2 ABOUT HERE}

We expected that either version of the $A T F_{-}$waitperiod variable might carry a negative sign 
but also that it never should come in with a statistically significant coefficient, as indeed it never did. This variable measures whether in any given year a state imposed a waiting period on endpurchasers and, if so, for how many days (but measured in hours). One would not expect, however, that this should affect the presence of firearms manufacturing in a state. Firearms are sold in a national, indeed global, market and a waiting period requirement in any one state should not affect the number of firearms manufacturing establishments there. Likewise, whether state law preempts or permits ordinances at the substate level in regard to firearms end-use should not affect the number of manufacturing premises in the state. There may be a positive sign on the parameter (preempting additional municipal regulation being favorable to the industry) but in only one of our regressions did this variable turn up with a (weak) statistically significant coefficient. The findings are shown in Tables 4 and 5 in Section III.

Similarly, one would not expect that whether or not a state restricts firearms commerce with its immediate neighboring states would affect the establishment of a manufacturing site. At first sight, one might believe that a manufacturer of hunting rifles in Montana, say, might be discouraged by an interstate commerce restriction but the relevant (federal and) state laws do not prohibit the manufacturer from shipping hunting rifles to a neighboring state for sale through dealers there. To illustrate the point: In 2005, the relevant provision in Montana state law reads: "Residents of Montana may purchase any rifle or rifles and shotgun or shotguns in a state contiguous to Montana," and similarly for residents of contiguous states wishing to purchase in Montana (Art. 45-8-341 \& 45-8-342). The important point here is, again, that the interstate restriction (or permission) pertains to the end-user (demander), not to the manufacturer (supplier). In our regressions, we neither expected nor found a statistically significant sign, in 
either direction, for this variable. ${ }^{12}$ However, for the state licensing variable (ATF_statelicense), we did expect a statistically significant negative sign: The presence of a state license requirement in addition to the federal license requirement would be associated with a smaller number of firearms premises hosted in the state and for the years in which the law was in effect. In all the regressions we ran (with the full set of controls), this turned out to be the case. ${ }^{13}$ Even as state licensing requirements do not seem particularly onerous, and most often concern dealers rather than manufacturers, they reflect state sentiment directed at the supply side rather than the demand side of the market.

\subsection{B/L data}

Another dataset that codes state firearms laws comes from the combined effort of the Brady Campaign to Prevent Violence (in Washington, D.C.) and the Law Center to Prevent Gun Violence (in San Francisco, CA). ${ }^{14}$ We refer to this as the B/L data. As for the ATF/Laws data, the $\mathrm{B} / \mathrm{L}$ data origin and coding are not ideal for research purposes. Both organizations are "antigun," which may be presumed to color their selection and reading of state law, and at the time we collected the data neither organization kept a full set of data on its website. We obtained the B/L State Scorecard sheets for 2007 to 2011 - presumably covering the calendar or legislative years 2006 to 2010 - through internet searches and also directly from Dr. Eric Fleegler (see Fleegler, et al., 2013). One difficulty is that the various Scorecards are not fully comparable

\footnotetext{
${ }^{12}$ In the GMM estimates (Appendix Table D1), however, this variable does generate positive coefficients at the $5 \%$ level of statistical significance. If one is inclined to view an interstate commerce restriction as negatively affecting manufacturers in immediately adjacent states, then one might in fact expect more manufacturers to locate in-state.

${ }^{13}$ This is also true in the case of the Poisson (Appendix C) and the GMM (Appendix D) estimates.

14 The Brady Campaign to Prevent Violence (Washington, D.C.) produces its annual State Scorecard in conjunction with the Law Center to Prevent Gun Violence (San Francisco, CA). Reports were published in 2007, 2008, 2009, 2010, and 2011 but appear to refer to the years 2006 to 2010, respectively. In addition, Mayors Against Illegal Guns (MAIG, 2010) produced a one-time effort to code state firearms laws. As of this writing, the Brady Campaign is at www.bradycampaign.org and the Law Center at www.smartgunlaws.org [both last accessed on 5 February 2016].
} 
across years. Thus, the $\mathrm{B} / \mathrm{L}$ data show the same five rubrics for all the years (Curb Firearm Trafficking; Strengthen Brady Background Checks; Child Safety; Guns in Public Places and Local Control; and Ban Assault Weapons) but the rubrics are not divided into headings and subheadings in a consistent way throughout the data span. For example, in the 2007 State Scorecard, the Strengthen Brady Background Checks rubric consists of three categories with a total of 12 subheadings. In 2011, the same rubric consists also of three categories and 12 subheadings - but different ones!

Therefore, like Fleegler, et al. (2013), we felt that the B/L data were not usable in their original form, and we reconstructed the rubrics to obtain consistent measures for the relevant time period (see Table 2, Panel B, and Appendix Table A1). Our B/L_trafficking variable is an aggregate in regard to various measures that pertain to the curbing of firearms trafficking; $B / L \_$checks is an aggregate dealing with the strengthening of background checks; $B / L \_$childsafe is an aggregate capturing child safety provisions; and $B / L \_$publicplace is a measure of regulations regarding firearms use in public places and the degree of municipal control. In creating these index variables, we kept the original $\mathrm{B} / \mathrm{L}$ scores but reweighted them.

For our version of the $\mathrm{B} / \mathrm{L}$ data, we expect the $B / L \_$trafficking and $B / L \_$checks variables to be negatively related to the number of manufacturing plants hosted by a state in the belief that both are proxies for the general regulatory environment manufactures face when setting up a manufacturing establishment in a specific state. The first of these might even be statistically significant if anti-trafficking state law were thought to "hold off" some potentially unscrupulous manufacturers; the second should not be expected to result in a statistically significant coefficient as state background checks may not add much in practice to federal background checks and clearly are directed at end-users, not manufacturers. Our findings confirm our expectations 
(Tables 6 and 7 in Section III). Our findings also hold in the Poisson and GMM estimates.

A child access prevention (CAP) requirement, $B / L \_$childsafe, could conceivably affect plant siting, depending on what the specific state law requires. If the law requires the use of an aftermarket firearms lock, for instance, this would not be expected to affect manufacturers' site decision and thus should not affect the number of plants in a state. But if a law required a lock to be built into the weapon in the first place, this might be perceived as a regulation directed against manufacturers and hence affect the number of plants established. The cost would still be incurred in order to sell firearms in that state but manufacturers may not wish to "reward" that state with jobs. (This is an issue, for instance, in the ongoing debate over microstamping a weapon's firing pin, which would add to manufacturing costs.) In practice, most child safety provisions make the end-user legally responsible for preventing firearms access by children (DeSimone, et al., 2013). Thus, this is a consumption-related rather than a production-related variable, and we would not expect it to be statistically significant in relation to the number of firearms establishments hosted in any given state or year. Finally, B/L_publicplace also relates to the use of firearms (the demand side) and, although the sign might be negative, we do not expect it to affect the number of firearms plants in a statistically significant way in any given state or year. For both of these variables this, again, is what we find in our regressions run with all control variables (see Tables 6 and 7 in Section III).

\subsection{V/H data}

Finally, a dataset laboriously assembled by Jon S. Vernick and Lisa M. Hepburn (Vernick and Hepburn, 2003) codes state laws from 1970 to 1999 into five major rubrics (State Laws Banning Certain Firearms; Sales and Purchase Restrictions (1); Sales and Purchase Restrictions (2); Possession, Carrying, and Storage Laws; and Sentence Enhancement Laws for Possession or Use 
of Firearm) with a total of 18 variables. As for the other datasets, we were unable to obtain an electronic copy of the dataset and thus hand-coded all variables from the published paper record. In the Sales and Purchase Restrictions (1) category for example, there are five variables, the first of which asks whether a state license is required to affect a firearms purchase. If not, we coded this as 0 ; if yes, we coded this as 1 for the year in which the requirement was in effect. ${ }^{15}$ We then regrouped the $18 \mathrm{~V} / \mathrm{H}$ variables as follows (see Table 2, Panel C, and Appendix Table A1). A V/H_trafficking variable refers to the potential for firearms trafficking. It consists of two underlying variables, namely whether there is a state dealer license and inspection requirement, and/or whether there is a one-firearm-per-month purchasing limit (the state license component of this variable is analogous, but not equal, to a similar variable in the ATF/Laws dataset). $V / H \_$check refers to background check variables in the $\mathrm{V} / \mathrm{H}$ dataset (background checks for sales from dealers; background checks for private-party (nondealer) sales; permit for firearms purchase required; firearms registration required). Unlike for the $\mathrm{B} / \mathrm{L}$ dataset, we expect that this variable might turn up with a statistically significant negative coefficient - as indeed it did because the laws coded here predate the introduction of background checks at the federal level. $V / H \_$childsafety refers to child safety laws (which contains only one variable); V/H_bans refers to bans of certain firearms (assault weapons ban; Saturday Night Specials ban); and $V / H \_$sentencing refers to the punishment of crime involving firearms (mandatory minimum sentences).

We expected the signs of $V / H \_t r a f f i c k i n g, V / H \_c h e c k s$, and $V / H \_c h i l d s a f e$ to be the same as for the corresponding $\mathrm{B} / \mathrm{L}$ variables, i.e., negative, negative, and either negative or positive,

\footnotetext{
15 Vernick and Hepburn (2003) themselves attach extensive cautions to their coding, far too numerous to repeat or even summarize here, and we urge readers to read their original work to understand inherent data limitations.
} 
respectively. As regards $V / H \_b a n s$, we expected a negative coefficient (and maybe statistically significant; see the discussion in the final paragraph of this subsection.) Finally, although the

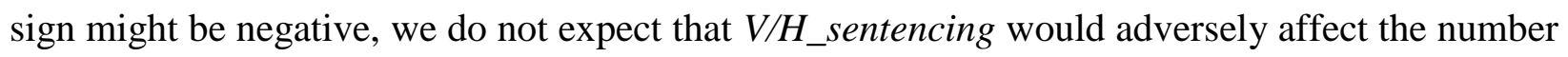
of manufacturing plants per state in a statistically significant way. On the whole, the empirical results for $\mathrm{V} / \mathrm{H}$ conform to those of $\mathrm{ATF} / \mathrm{Law}$ and $\mathrm{B} / \mathrm{L}$ even if they are somewhat less clear statistically (see Tables 8 and 9 in Section III).

Although coming from different sources, note the seeming resemblance for the first three indices of our versions of the $\mathrm{B} / \mathrm{L}$ and the $\mathrm{V} / \mathrm{H}$ datasets. They code for laws aimed at reducing firearms trafficking, improving background checks, and enhancing child safety. We therefore would expect some coherence across the estimates using the $\mathrm{B} / \mathrm{L}$ and the $\mathrm{V} / \mathrm{H}$ datasets. One might even argue that $B / L \_p u b l i c p l a c e$, a measure of regulations regarding firearms use in public places and the degree of municipal control, carries some resemblance to $V / H \_b a n s$, which refers to bans of certain firearms (assault weapons ban; Saturday Night Specials ban). Hence, confronting the results obtained for these two sets of regulatory variables, although obtained for different time periods (2006-2010 and 1986-1999, respectively), could help confirm (or not) our hypothesis and point to some degree of consistency over a fairly long time period. ${ }^{16}$

Manufacturers are subject to federal and state laws such as Occupational Health and Safety laws, of course, but to our knowledge there are no state laws that specifically target manufacturers for being producers of firearms. What state laws target are not production, but the product, its sale, and its use. Neither in our personal observations nor in any talks with firearms manufacturers or federal and state public officials have we encountered state laws and

\footnotetext{
${ }^{16}$ Note that even though we do not compute a single aggregate index across all the $\mathrm{B} / \mathrm{L}$ and $\mathrm{V} / \mathrm{H}$ data, respectively, we did retain the variable weights assigned by the respective original scorers.
} 
regulations specifically aimed at the manufacture of firearms. Judging from the news media, industry association reports, and individual firearms manufacturing firms, the industry itself also appears merely to refer to the relative degree of restrictions placed on its products, not on their production. In Beretta USA's case, for example, “Gun laws adopted in Maryland last year [2013] ban some of the types of firearms that Beretta manufactures from being bought or sold in the state" (Washington Times, 29 January 2014). Maryland's new laws neither prohibit Beretta to sell its products elsewhere nor does locating elsewhere permit Beretta to sell weapons that are restricted in Maryland. Therefore, incurring the cost of locating outside of Maryland makes no strictly economic sense. Maryland's new laws may be viewed as a tax, reducing profit, and this fact is not reversed by locating elsewhere. However, laws intended to restrict the product and its distribution may collide with firearms manufacturers' preferences, in particular with their and their customers' self-perceived identity (Akerlof and Kranton, 2000). If held with sufficient strength, identity may then affect the number of manufacturing premises in a state. In sum, since there are no production-targeted laws, one can only assemble and code consumption-targeted laws. Some of these the industry does not disagree with (e.g., criminalizing firearms misuse), and therefore one would not expect these laws to adversely affect establishment decisions; but other laws do speak to the core of law-abiding producers and users (e.g., "assault weapon" bans) and they may thus serve as proxies for how laws may affect establishment decisions.

\section{Control variables}

All regressions first were run without and then with a variety of control variables. ${ }^{17}$ These come

\footnotetext{
17 A broad economic literature deals with determinants of the physical location of industrial sites (for a recent survey, see Arauzo-Carod, et al., 2010). It generally focuses on simply observing the number of new firms or plants in a given space. A discrete choice model then captures factors shaping the agent's decision and factors related to the set of alternative sites from which the choice is made. Although we focus on the number of existing plants in a
} 
in three sets: private sector-related controls, public sector-related controls (including possible predispositions of state legislatures in regard to firearms-related legislation), and controls for measures of crime (see Table 3, which also shows descriptive data for the other datasets). The private sector-related controls include (1) the logarithm of the total state population (log_population) with data taken from the U.S. Census Bureau; (2) the number, also in logarithms, of total manufacturing establishments in a state (log_num_firms), measured as the annual average establishment count in private manufacturing industry and taken from the Quarterly Census of Employment and Wages (QCEW), Department of Labor Statistics, U.S. Department of Labor; (3) union membership (union_member), measured as the number of employed workers who are union members in private manufacturing industry and taken from the Current Population Survey (CPS), Outgoing Rotation Group (ORG); and (4) state industrial wage rates (wage_quotient), measured as the total wage location quotient relative to the entire U.S. in private manufacturing industry, taken from the QCEW. We control for these factors because it might be expected that (1) states with larger populations host larger numbers of manufacturers per se, including firearms manufacturers, (2) states with a larger manufacturing base host larger numbers of firearms manufacturers (and maybe compete more for qualified workers), (3) states with high rates of workforce unionization might host fewer firearms manufacturers, and (4) states with higher industrial wage rates might host fewer firearms manufacturers as well.

\section{TABLE 3 ABOUT HERE}

Regarding public sector-related control variables, we include total state revenue from

given state, rather than the number new plants, our estimates take the usual determinants of industrial location into account. Broadly speaking, these are economic factors (such as agglomeration economies, market structure, or labor force characteristics) and institutional factors (such as public sector intervention). 
taxation per capita (taxes_pc), with the data taken from the U.S. Census Bureau. A priori, we expect a negative sign with respect to the number of firms operating in a state (the higher the per capita tax burden, the smaller the number of premises). We also include a political balance variable. Although few lawmakers will be elected primarily on the basis of their views regarding firearms, when such legislation does come up for a vote, a "pro" or "con" bias may reveal itself. We were unable to find U.S. Census data on annual political party representation in upper and lower state houses, but Wikipedia lists (and reliably sources) such data. We recorded and coded these as follows. If state Senate Republicans held the majority over state Senate Democrats in any year, the resulting $>1$ ratio was coded as +1 (and a $<1$ ratio was coded as -1 ). We coded similarly for the state House. Thus, a combined score (political_balance) of $+2(-2)$ indicates that Republicans (Democrats) had the majority of votes in both state houses in any given year. A combined score of zero (0) indicates that one house was dominated by one party and the other house by the other party. Finally, a combined score $+1(-1)$ indicates that one house was evenly split between the parties (resulting in a ratio of 1 , and a coded score of 0 for that house), and that the other house was dominated by either Republicans $(+1)$ or by Democrats $(-1) .{ }^{18}$ In many instances, there is no variation across the 25 data years, amounting to a fixed effect condition. For example, and perhaps surprisingly, the Alabama legislature is dominated by Senate Democrats and House Democrats, yielding a -2 score across all data years (absorbed in this case in the Alabama fixed effect). We had no expectations in regard to the sign of this variable but

\footnotetext{
18 The data come from https://en.wikipedia.org/wiki/Political_party_strength_in_Pennsylvania (last accessed 28 November 2015). At the bottom of the Pennsylvania page are the relevant links to each of the other U.S. states. From time to time, members of other parties join the legislature. We coded these as "other," but their occurrence is relatively rare (e.g., only in 3 out of 25 years in the Alabama Senate, and no occurrence at all in the Alabama House), and we therefore ignored "other" for our purposes. Unique among the states, Nebraska features a unicameral legislature and is therefore dropped in the estimations using the political balance variable.
} 
thought that it would not turn up in a statistically significant way, as indeed it never did, because the seeming Republican-Democratic party split at the federal level does not necessarily play the same way at the state level, Alabama being a case in point.

We also introduce controls that account for the level of crime in a given state; hence, we include variables measuring violent crime (violent_crimes_pc) and property crime (property_crimes_pc), both per capita, with the data taken from the Disaster Center <disastercenter.com/crime/> which provides access to crime statistics compiled by the Federal Bureau of Investigation. For both crime variables, we expect a negative sign (even firearms manufacturers do not like to operate in relatively insecure states), which is what we found, ${ }^{19}$ but in neither case would we necessarily expect a statistically significant coefficient.

\section{ESTIMATION METHODS AND RESULTS}

We ran regressions with the total number of firearms manufacturing plants per state per year (num_plants) as the dependent variable. ${ }^{20}$ We ran standard panel fixed effects regressions with robust standard errors and, as robustness checks, also ran Poisson count data and GMM dynamic panel data regressions. ${ }^{21}$ We take into account the panel structure of our data and introduce state

\footnotetext{
${ }^{19}$ The finding carries over to the Poisson and GMM estimations, except for GMM with the V/H variables.

${ }^{20} \mathrm{We}$ also performed regressions using the number of firearms produced at each of the plants. We found no statistically significant results of the regulatory variables on production levels: State laws seem to affect the decision to establish a premise in the first place, not the level of production once an establishment decision has been made and sunk costs have been incurred (these regressions are not reported here but are available upon request).

${ }^{21}$ As discussed by Wooldridge (2016) specifying robust standard errors is equivalent to specifying errors clustered at the state level, where the state is the variable that identifies the panel. The Poisson estimates (see Appendix C) are performed because of the nature of our dependent variable. As explained, our dependent variable is simply an observation about the number of plants located in, say, Florida. It could well be the case that a specific firm may have been located in that state since, say, 1964 but decided to engage in firearms production only in, say, 1993. Hence, the plant establishment year (in 1964) may well be different from the observation year (1993) in the ATF/AFMER record. What we explain is the number of plants in state $x$ in period $y$; we do not observe the decision to move to state $x$ in period $y$. The dynamic panel data GMM estimations (see Arellano and Bond, 1991) also are
} 
and time fixed effects in all the regressions performed. We report in the main text the linear regression results which on the whole are as good as the Poisson results and the GMM estimates shown in the Appendices. It is reassuring that our results are rather consistent both within and across the chosen estimation procedures (for discussion, see Section IV).

We report two tables of results each for the estimations: (1) for the ATF/Laws data (Tables 4 and 5); (2) for the $\mathrm{B} / \mathrm{L}$ data (Tables 6 and 7); and (3) for the $\mathrm{V} / \mathrm{H}$ data (Tables 8 and 9). In each case, the first table introduces all the regulatory indices at the same time and the control variables progressively (private sector, public sector, and crime-related controls); the second table reverses this. Except for regression constants, all coefficients that are statistically significant (at the usual levels of $0.01,0.05$, and 0.10 ) are presented in the tables in bold type-font.

Table 4 reports on the matching of ATF/AFMER with ATF/Laws data for 1997-2010 and 2000-2010 (given that some data for 1998 are missing) and for our control variables. Since the results are virtually unaltered by the missing observations for 1998, Table 5 uses the entire 1997 to 2010 time period. The goodness of fit obtained for the estimations with both the ATF/Laws and the $\mathrm{B} / \mathrm{L}$ data is similar at around 0.60 (Tables 4 to 7 ). A different goodness of fit is obtained for the $\mathrm{V} / \mathrm{H}$ data (around 0.18). In the latter case (Tables 8 and 9), to cover the 1986 to 1999 time period, it was necessary to reduce the number of control variables as the data for some controls are available only as from 1990 and 1992 onward, respectively.

Reading Tables 4 and 5 for our ATF/Law variables of interest, the ATF_statelicense variable is statistically significant and, as expected, negatively related to the number of plants producing firearms in a given state. With one weak exception, the other law variables are not statistically

performed as a robustness exercise: Since we use the stock of establishments as the independent variable, it could be the case that the lagged stock affects the current stock (see Appendix D). 
significant. Similarly, the results for the B/L data (Tables 6 and 7) show that the only regulatory index variable that is consistently statistically significant is $B / L \_$trafficking. Again, as expected, it is negatively related to the number of plants producing in a given state. The results for the $\mathrm{V} / \mathrm{H}$ data (Tables 8 and 9), covering the 1986-1999 data span, show fairly consistent statistical significance only for $V / H \_c h e c k s$, which is negatively related to the number of firearms plants producing a given state.

As mentioned, all estimations include state and time fixed effects as well as a number of control variables. Regarding the controls, on the whole we obtain the expected results, and they are fairly stable across the estimations. Population seems to play a positive and statistically significant role with respect to the number of plants located in a given state. More populous states may be expected to host correspondingly more entrepreneurs and businesses, including those producing firearms. (Or perhaps more populous states, with a larger number of potential employees, have lower average wages.) Higher state tax revenues (more fiscal pressure) are associated in a negative and statistically significant way to the number of plants producing in a given state. An elevated level of crime, especially violent crime, seems to play a negative role with respect to plant numbers. Higher rates of unionization and higher industrial wages paid in a given state also seem to play an adverse role with respect to the number of firearms plants in a given state.

\section{TABLES 4 TO 9 ABOUT HERE}

\section{DISCUSSION AND CONCLUSION}

The key table in this paper, Table 10, summarizes all of our empirical findings. Bearing in mind that the law variables - ATF/Laws (1997-2010), B/L (2006-2010), and V/H (1986-1999) - are 
not strictly comparable, the results should be read downward within each of the two-column sets and only with caution across them. Reading across, however, is attractive because of the 25year-long time-period then covered, 1986 to 2010.

Table 10 is constructed as follows. The first column lists the three sets of law variables, plus the control variables. There then follow three sets of columns, one each for the results of the regressions with each set of law variables. The negative and plus signs indicate the sign of the estimated parameters, taken from Tables 4 to 9 . A checkmark says that the sign goes into the expected direction Shaded cells indicate that the estimated parameter is statistically significant (at 0.10 or better).

For the ATF/Laws columns, the law variables conform to our expectations. The state license requirement is associated with a smaller number of firearms premises hosted by a state. The requirement is not onerous but may indicate a stricter regulatory "climate" in the state. The other variables are for the most part not statistically significant but go in the direction we would expect except for the interstate commerce with contiguous states variable on which we had no expectation for the sign, only that it not be statistically significant (which it is not). The signs for the private sector, public sector, and crime variables are for the most part in the expected direction, and several are statistically significant. There are no statistically significant coefficients contrary to our expectations.

\section{TABLE 10 ABOUT HERE}

For the B/L columns, recall that the law variables are composites, each constructed from several underlying variables (see Table 2 and Appendix Table A1). The B/L_trafficking variable is statistically significant and in the expected direction (negative) and is a summary measure intended to capture the existence of state-level firearms dealer regulation; the imposition of 
limits to bulk firearms purchases; laws to assist crime gun identification; and a reporting requirement for lost or stolen firearms. Together they are aimed at curbing firearms trafficking. While no legitimate firearms manufacturer would object to this on a per se basis, at the perceptual level such efforts do indicate a less firearms-“friendly" state climate for the firearms industry. The remaining law and control variables are (almost) all in the expected direction, where we had expectations, and no statistically significant coefficient is contrary to expectations.

Like their $\mathrm{B} / \mathrm{L}$ analogues, the $\mathrm{V} / \mathrm{H}$ index variables are composites (see Table 2 and Appendix Table A1). Here, the trafficking variable consists of state legislation to restrict firearms sales to one firearm per month; a state dealer license and inspection requirement; and the imposition of a minimum age for the purchase and sale of firearms. In our estimations, the signs point in the opposite direction to what we expected but the coefficients for the index are not statistically significant. The other law index variables all point in the expected direction (where we had an expectation), and one is statistically significant. For the control variables, the results also are as expected except for the population variable, the sign of which goes in the opposite direction of what we expected, but it is not statistically significant in any case.

One finding that seems puzzling is that the trafficking variable for the $\mathrm{B} / \mathrm{L}$ data shows the expected negative sign and is statistically significant, whereas for the $\mathrm{V} / \mathrm{H}$ data it is positive, although not statistically significant. Similarly, although both carry the expected negative sign, the check variable for the $\mathrm{B} / \mathrm{L}$ data (state universal background check requirement and state permit needed to purchase firearms) is not statistically significant while a similar check variable for the $\mathrm{V} / \mathrm{H}$ data (state permit needed to purchase a firearm; firearms registration required; background checks for sales from dealers; background checks for private sales) is statistically significant. In other words, in one case trafficking is significant and check is not $(\mathrm{B} / \mathrm{L})$; in the 
other case we have the opposite result $(\mathrm{V} / \mathrm{H})$. The difference in the years covered may explain this: federal-level background checks were introduced only as of November 1998. Thus, in the V/H data (1986-1999), state-level background checks were the only kind of checks conducted and might be expected to carry a significant negative coefficient on the parameter; in contrast, the $\mathrm{B} / \mathrm{L}$ state-level data for 2006-2010 are additional to federal background checks and might not be expected to make much of an additional difference in terms of the number of established plants. And as regards the trafficking variables, the potential for firearms trafficking would seem to have mattered more in the 2000s (B/L) than it mattered in the late 1980s to $1990 \mathrm{~s}(\mathrm{~V} / \mathrm{H})$.

Taken as a whole, for the vast majority of our variables the results conform to the expectation that more "lax" firearms law is associated with larger numbers of firearms manufacturing plants in a given state and year, 1986 to 2010. The laws that our variables capture are not about production; instead, they are about the product (e.g., bans), its distribution (e.g., state license for dealers), its monitoring (e.g., firearms registration; purchase restrictions), and its end-use (e.g., child access prevention; sentencing laws). They would seem to capture a given state's overall "attitude" and "business climate" toward firearms manufacturers and might be seen to influence a firearms manufacturer's identity and, hence, preference to establish a manufacturing premise in one state or another.

In a way, our findings then are reassuring. The firearms industry is "just another industry" in that it responds to economic incentives and disincentives, of which relevant state firearms laws are an example: State laws play but an incremental role in determining the number of firearms manufacturing plants in a state; they are one factor among many. If this is the correct interpretation of our findings, then both sides in the "gun control" debate - pro and con - should be pleased with the results: Both might argue "I told you so: Laws matter!" The more 
dispassionate, scholarly point is that to the best of our knowledge we now have a first-time quantitative, empirical confirmation that state firearms laws matter in influencing the number of firearms manufacturing plants established in a state and that we have a hint about the direction in which further tightening or relaxation of relevant law might go. For instance, if there is a bit more "stickiness" to the supply-side of the market than is often presumed, states can impose higher bars on some aspects of firearms legislation without fear of a manufacturing exodus. To the extent that states confine their legislative forays to laws concerning firearms purchasing specifically rather than manufacturing licenses, for instance, they may not need to worry overmuch about scaring off these corporations. ${ }^{22}$

Indeed, our annual, descriptive record of our ATF/AFMER data tells us that, once situated in one state, it is exceedingly rare for a firearms manufacturer to move its entire operation to another state. (And our statistical procedure is correspondingly careful in that it measures the number of plants, not the movement of manufacturing premises from one state to another.) The "lock, stock, and barrel" movement of a company like PTR-91, which moved in 2013 from Connecticut to South Carolina, is the exception. The norm is given by examples such as Kahr Arms, Remington Arms, Ruger, and Beretta USA: Manufacturing premises in some states "atrophy" over time as companies shift production gradually toward new establishments in new states. This process is slow, evolves over long periods of time, and is as wrapped up with the private and public sector-related control variables, especially the cost of doing business (e.g., taxation, unionization, wage rates, and competition for qualified workers given the existing

\footnotetext{
${ }^{22}$ We are grateful to an anonymous reviewer for this policy-relevant point.
} 
manufacturing base in a state) as it is wrapped up with firearms law. ${ }^{23}$ In this regard, even the

PTR-91 example fits the bill: News reports spoke as much of the economic incentives offered as

they spoke of the firearms-"friendly" culture that ostensibly induced the company to move from

Connecticut to South Carolina in 2013 (Ghosh, 2014).

As prominently exemplified by the country's automotive industry, it is common knowledge

that the U.S. manufacturing base has slowly shifted out of the country's Northeast region to the

Midwest, South, and Southwest (from "rustbelt" to "sunbelt"). As the market share of U.S.

automotive brands has declined, its spatial concentration, once focused on Detroit, Michigan, has

declined as well. Conversely, non-U.S. brands have chosen to locate in the Midwest and the

South. ${ }^{24}$ Something similar has happened, and continues to happen, with the firearms industry -

albeit for somewhat different reasons.

\footnotetext{
${ }^{23}$ For example, Remington Arms, a storied rifle brand with a nearly 200 -year-long corporate history, has been located in Ilion, New York, since 1828. In the wake of repeated ownership changes, corporate headquarters moved several times, most recently in 1996 to Madison, North Carolina. Over the years the firm has closed various facilities in the North (e.g., in Connecticut) and generally expanded in the South (e.g., it opened a new firearm production plant in 1997 in Mayfield, Kentucky, and in February 2014 announced an expansion to take place at its Huntsville, Alabama, establishment). Thus, recent industry talk about Remington possibly closing its aging Ilion, NY, plant and consolidating its manufacturing operations to the South may reflect as much a general commercial discussion within the parent company as a political one having to do with firearms laws. Similarly, from 1995 to 1996 another prominent firearms maker, Sturm Ruger \& Co. (Ruger, for short), while retaining revolver and rifle production at its Newport, New Hampshire, facility, moved the vast majority of its pistol production from Southport, Connecticut, to Prescott, Arizona. The remainder of its pistol production was moved to New Hampshire and, although corporate headquarters remain there, the Connecticut manufacturing operations were closed. On 8 May 2013, Ruger announced the building of a third manufacturing plant, for rifle production, to be located in Mayodan, North Carolina. Local news media reported that the company was offered several millions of dollars worth of incentives (http://www.journalnow.com/business/business_news/local/article_69d18da6-4705-11e3-b38c-019bb30f31a.html).

And on 29 January 2014, Beretta USA (the U.S. subsidiary of an Italian brand) announced that it would open a new production facility in the state of Tennessee, near Nashville, rather than expand its operations at its current Maryland location, just south of Washington, D.C. The company stated that its primary selection criterion was related to firearms regulation: "We started our search by looking only at States that have a consistent history of support for and likelihood of future support for Second Amendment rights" (http://www.beretta.com/en-us/transcript-of-jeff-rehsspeech-on-new-plant-in-tennessee/). Also see the 29 January 2014 Washington Times news account at http://www.washingtontimes.com/news/2014/jan/29/beretta-announces-tennessee-plant-says-its-notlea/\# ixzz2rzAntvLW). But since those laws are about the product, not the production, Beretta's statement signals more about its sentiment and location preferences than it does about its cost of doing business.

${ }^{24}$ Thus, foreign nameplates opening plants as from the 1980s onward are located as follows: Toyota (in IN, KY, MS, TX); Honda (AL, IN, OH); Nissan (MS, TN); Fuji Heavy Industries (i.e., Subaru) (IN); Mitsubishi (IL); Volkswagen (TN); Hyundai (AL); Kia (GA); BWM (SC); Daimler (i.e., Mercedes-Benz) (AL); and Volvo (SC).
} 


\section{ACKNOWLEGEMENTS}

We thank Mr. Mario Barrera, Ms. Angela Mediavilla, and Mr. Sergi Sansano for assistance with data entry. We thank Dr. Eric Fleegler (Boston Children's Hospital), Dr. David Hemenway (Harvard University), Dr. Philip J. Cook (Duke University), and Mr. Sam Hoover (Law Center, San Francisco) for assistance with data searches. We also thank anonymous reviewers and the editor for helpful comments. All remaining errors are ours. Jurgen Brauer acknowledges support from the Chair in Markets and Industrial Policy at the Barcelona Institute of Economics (IEB), University of Barcelona, for a visiting fellowship in May 2012. Daniel Montolio acknowledges financial support from grant 2014SGR420 (Catalan Government) and from grant ECO201341886-R from Spain’s Ministerio de Economía y Competitividad. 
Table 1. Number of plants per state and year in selected years (dependent variable).

\begin{tabular}{|c|c|c|c|c|c|c|}
\hline & 1986 & 1990 & 1995 & 2000 & 2005 & 2010 \\
\hline ALASKA & 0 & 1 & 0 & 1 & 0 & 1 \\
\hline ALABAMA & 2 & 3 & 4 & 2 & 3 & 11 \\
\hline ARKANSAS & 3 & 5 & 5 & 3 & 7 & 20 \\
\hline ARIZONA & 11 & 12 & 14 & 13 & 24 & 62 \\
\hline CALIFORNIA & 22 & 24 & 16 & 19 & 14 & 27 \\
\hline COLORADO & 3 & 6 & 3 & 3 & 5 & 20 \\
\hline CONNECTICUT & 12 & 10 & 10 & 11 & 16 & 17 \\
\hline DELAWARE & 0 & 1 & 0 & 0 & 0 & 1 \\
\hline FLORIDA & 12 & 19 & 18 & 15 & 25 & 54 \\
\hline GEORGIA & 8 & 7 & 7 & 6 & 11 & 27 \\
\hline HAWAII & 0 & 0 & 0 & 0 & 0 & 0 \\
\hline IOWA & 0 & 0 & 0 & 1 & 1 & 8 \\
\hline IDAHO & 1 & 1 & 6 & 7 & 9 & 23 \\
\hline ILLINOIS & 4 & 8 & 7 & 7 & 10 & 20 \\
\hline INDIANA & 3 & 3 & 3 & 3 & 3 & 17 \\
\hline KANSAS & 1 & 1 & 3 & 3 & 1 & 14 \\
\hline KENTUCKY & 1 & 0 & 2 & 5 & 6 & 15 \\
\hline LOUISIANA & 4 & 2 & 2 & 2 & 2 & 2 \\
\hline MASSACHUSETTS & 4 & 5 & 9 & 6 & 9 & 9 \\
\hline MARYLAND & 3 & 3 & 3 & 6 & 7 & 12 \\
\hline MAINE & 2 & 3 & 2 & 3 & 4 & 7 \\
\hline MICHIGAN & 2 & 6 & 0 & 4 & 5 & 16 \\
\hline MINNESOTA & 3 & 3 & 6 & 8 & 14 & 23 \\
\hline MISSOURI & 1 & 3 & 6 & 11 & 16 & 40 \\
\hline MISSISSIPPI & 0 & 0 & 0 & 1 & 0 & 4 \\
\hline MONTANA & 3 & 5 & 5 & 9 & 8 & 22 \\
\hline NORTH CAROLINA & 0 & 7 & 4 & 5 & 4 & 39 \\
\hline NORTH DAKOTA & 0 & 1 & 1 & 0 & 0 & 0 \\
\hline NEBRASKA & 1 & 2 & 2 & 3 & 3 & 11 \\
\hline NEH HAMPSHIRE & 1 & 2 & 4 & 5 & 6 & 13 \\
\hline NEW JERSEY & 1 & 1 & 0 & 0 & 2 & 2 \\
\hline NEW MEXICO & 3 & 3 & 0 & 1 & 1 & 7 \\
\hline NEVADA & 1 & 5 & 2 & 5 & 7 & 16 \\
\hline NEW YORK & 3 & 6 & 3 & 6 & 7 & 19 \\
\hline $\mathrm{OHIO}$ & 6 & 11 & 13 & 16 & 19 & 36 \\
\hline OKLAHOMA & 3 & 4 & 3 & 7 & 12 & 29 \\
\hline OREGON & 7 & 4 & 10 & 6 & 9 & 30 \\
\hline PENNSYLVANIA & 11 & 15 & 12 & 10 & 14 & 35 \\
\hline RHODE ISLAND & 0 & 0 & 0 & 0 & 0 & 1 \\
\hline SOUTH CAROLINA & 0 & 1 & 0 & 5 & 2 & 11 \\
\hline SOUTH DAKOTA & 1 & 2 & 3 & 8 & 6 & 13 \\
\hline TENNESSE & 2 & 9 & 8 & 6 & 8 & 23 \\
\hline TEXAS & 13 & 30 & 24 & 20 & 29 & 93 \\
\hline UTAH & 7 & 6 & 5 & 5 & 12 & 26 \\
\hline VIRGINIA & 0 & 4 & 3 & 1 & 7 & 33 \\
\hline VERMONT & 2 & 3 & 2 & 4 & 5 & 8 \\
\hline WASHINGTON & 4 & 8 & 9 & 9 & 12 & 20 \\
\hline WISCONSIN & 3 & 4 & 2 & 5 & 8 & 20 \\
\hline
\end{tabular}




\begin{tabular}{lcccccc}
\hline WEST VIRGINIA & 1 & 1 & 1 & 3 & 2 & 9 \\
WYOMING & 1 & 2 & 3 & 3 & 3 & 11 \\
\hline TOTAL & $\mathbf{1 7 6}$ & $\mathbf{2 6 2}$ & $\mathbf{2 4 5}$ & $\mathbf{2 8 2}$ & $\mathbf{3 7 8}$ & $\mathbf{9 7 7}$ \\
\hline
\end{tabular}

Source: Authors' calculations from Annual Firearms Manufacturing and Export Report (AFMER). 
Table 2. State law-related variables.

\begin{tabular}{|c|c|}
\hline Variable name & Rubric and description \\
\hline \multicolumn{2}{|c|}{ Panel A: Bureau of Alcohol, Tobacco, Firearms and Explosives (ATF) } \\
\hline ATF_waitperiod_l & Purchasing waiting period: Refers to the period between application for \\
\hline ATF_waitperiod_2 & firearms purchase and allowable receipt or delivery. \\
\hline ATF_statelicense & $\begin{array}{l}\text { License: Indicates the existence of state regulation requiring state licenses for } \\
\text { firearms dealers or manufacturers. }\end{array}$ \\
\hline ATF_preemption & $\begin{array}{l}\text { Preemption: Indicates that state jurisdiction overrides subordinate } \\
\text { jurisdictions in whole or in part. }\end{array}$ \\
\hline ATF_interstate & $\begin{array}{l}\text { Limits to interstate purchase and sale: Also known as "Contiguous State } \\
\text { Provisions," they indicate legislative limits to interstate purchase and sale } \\
\text { enacted by jurisdictions based on the (federal) Gun Control Act. }\end{array}$ \\
\hline
\end{tabular}

Panel B: Brady Center/Law Center data (B/L)

B/L_trafficking Curb firearm trafficking: Includes the existence of firearm dealer regulation; limits to bulk purchases; crime gun identification; and reporting of lost or stolen guns.

B/L_checks $\quad$ Strengthen Brady background checks: Includes universal background check; permit needed to purchase.

B/L_childsafe Child safety provisions: Includes child safety locks; child access prevention.

B/L_publicplace Guns in public places \& local control: Includes no guns allowed in workplace; no guns on college campuses; not a concealed carrying of weapons $(\mathrm{CCW})$ permit "shall issue" state; no state preemption.

\section{Panel C: Vernick/Hepburn data (V/H) \\ V/H_trafficking* Sales and purchase restrictions: Includes one-gun-per-month law; state dealer license and inspection; minimum purchase and sale age. \\ $V / H \_$checks* Sales and purchase restrictions: Includes permit to purchase; firearm registration required; background checks for sales from dealers; background checks for private sales. \\ $V / H \_$childsafe Possession, carrying, and storage laws: Includes child access prevention. \\ V/H_bans State laws banning certain firearms: Includes "Saturday Night Special” ban; assault weapon ban. \\ $V / H \_s e n t e n c i n g \quad$ Sentence enhancement laws for possession or use of firearm: Includes mandatory minimum sentence; minimum add-on sentence.}

Notes: See Appendix Table A1 for details regarding coding and code values. The variable words associated with each data source (_waiting_1, _waiting_2, ...,__bans,__sentencing) are shorthand expressions to indicate the predominant intent of the law variables captured in each index. Panel B: In the original B/L data there is a fifth rubric, Ban Military-Style Assault Weapons that did not show sufficient variability across states and years and was dropped from our estimations. Panel $\mathrm{C}$ : * The ordering of the five $\mathrm{V} / \mathrm{H}$ rubrics has been altered to obtain indices comparable to those obtained from B/L. 
Table 3. Descriptive statistics.

\begin{tabular}{|c|c|c|c|c|c|c|}
\hline Variable name & Period & Obs. & Mean & St. Dev. & Min & Max \\
\hline num_plants (dependent var.) & $1986-2010$ & $1,250 * *$ & 7.17 & 8.64 & 0 & 93 \\
\hline ATF_waitperiod_1 & $1997-2010 *$ & 686 & 0.25 & 0.43 & 0 & 1 \\
\hline ATF_waitperiodt_2 & $1997-2010 *$ & 684 & 42.64 & 117.72 & 0 & 720 \\
\hline ATF_statelicense & $1997-2010 *$ & 692 & 1.07 & 2.09 & 0 & 11 \\
\hline ATF_preemption & 1997-2010* & 688 & 0.80 & 0.40 & 0 & 1 \\
\hline ATF_interstate & $1997-2010 *$ & 650 & 0.65 & 0.48 & 0 & 1 \\
\hline$B / L \_$trafficking & 2006-2010 & 250 & 4.42 & 5.43 & 0 & 22 \\
\hline B/L_checks & 2006-2010 & 250 & 3.02 & 6.07 & 0 & 23 \\
\hline$B / L \_c h i l d s a f e$ & 2006-2010 & 250 & 1.78 & 2.52 & 0 & 9 \\
\hline B/L_publicplace & 2006-2010 & 250 & 4.32 & 1.97 & 0 & 8 \\
\hline V/H_trafficking & 1986-1999 & 700 & 1.95 & 2.77 & 0 & 10 \\
\hline V/H_checks & 1986-1999 & 700 & 1.36 & 1.97 & 0 & 8 \\
\hline V/H_childsafe & 1986-1999 & 700 & 0.64 & 1.47 & 0 & 4 \\
\hline V/H_bans & 1986-1999 & 700 & 0.30 & 0.82 & 0 & 4 \\
\hline V/H_sentencing & 1986-1999 & 700 & 1.29 & 0.58 & 0 & 2 \\
\hline log_population & $1986-2010$ & 1,250 & 15.03 & 1.01 & 13.02 & 17.43 \\
\hline log_num_firms & $1990-2010$ & 1,049 & 8.43 & 1.06 & 6.14 & 11.00 \\
\hline union_member & $1986-2010$ & 1,250 & 0.17 & 0.18 & 0.009 & 1 \\
\hline wage_quotient & $1990-2010$ & 1,049 & 1 & 0.39 & 0.16 & 2.10 \\
\hline taxes_pc & $1992-2010$ & 950 & 1.93 & 0.73 & 0.72 & 12.70 \\
\hline violent_crimes_pc & $1986-2010$ & 1,250 & 0.005 & 0.002 & 0.00 & 0.01 \\
\hline property_crimes_pc & 1986-2010 & 1,250 & 0.039 & 0.011 & 0.02 & 0.08 \\
\hline political_balance & $1986-2010$ & 1,199 & -0.313 & 1.703 & -2 & 2 \\
\hline
\end{tabular}

Notes: * 1998 ATF/Laws data is missing for some states. ** 50 states times 25 years yields 1,250 observations. 
Table 4. ATF/Laws. Panel data estimations with state and time fixed effects (I).

\begin{tabular}{|c|c|c|c|c|c|c|}
\hline & (1) & $\begin{array}{c}(2) \\
1997-2010\end{array}$ & (3) & (4) & $\begin{array}{c}(5) \\
2000-2010\end{array}$ & $(6)$ \\
\hline \multicolumn{7}{|c|}{ REGULATORY VARIABLES } \\
\hline - ATF_waitperiod_l & $\begin{array}{l}-0.549 \\
(1.581)\end{array}$ & $\begin{array}{l}-1.179 \\
(1.774)\end{array}$ & $\begin{array}{l}-0.354 \\
(1.886)\end{array}$ & $\begin{array}{l}-0.216 \\
(1.596)\end{array}$ & $\begin{array}{l}-1.069 \\
(1.819)\end{array}$ & $\begin{array}{c}-0.162 \\
(1.971)\end{array}$ \\
\hline - ATF_statelicense & $\begin{array}{c}-0.864 * * \\
(0.357)\end{array}$ & $\begin{array}{c}-0.899 * * \\
(0.374)\end{array}$ & $\begin{array}{c}-0.962 * * \\
(0.365)\end{array}$ & $\begin{array}{c}-0.850 * * \\
(0.356)\end{array}$ & $\begin{array}{c}-0.830 * * \\
(0.369)\end{array}$ & $\begin{array}{c}-0.895 * * \\
(0.359)\end{array}$ \\
\hline - ATF_preemption & $\begin{array}{c}3.283 \\
(3.421)\end{array}$ & $\begin{array}{c}4.508 \\
(3.118)\end{array}$ & $\begin{array}{l}4.919 * \\
(2.880)\end{array}$ & $\begin{array}{l}3.095 \\
(2.923)\end{array}$ & $\begin{array}{c}3.845 \\
(2.939)\end{array}$ & $\begin{array}{c}4.252 \\
(2.781)\end{array}$ \\
\hline - ATF_interstate & $\begin{array}{c}0.544 \\
(0.881)\end{array}$ & $\begin{array}{l}-0.182 \\
(0.871)\end{array}$ & $\begin{array}{l}-0.515 \\
(0.904)\end{array}$ & $\begin{array}{c}0.984 \\
(1.098)\end{array}$ & $\begin{array}{c}0.297 \\
(1.144)\end{array}$ & $\begin{array}{c}0.010 \\
(1.116)\end{array}$ \\
\hline \multicolumn{7}{|l|}{ ECONOMIC CONTROLS } \\
\hline - log_num_firms & $\begin{array}{l}-11.416 \\
(10.132)\end{array}$ & $\begin{array}{c}-3.334 \\
(10.586)\end{array}$ & $\begin{array}{c}-1.762 \\
(10.731)\end{array}$ & $\begin{array}{l}-19.051 \\
(12.985)\end{array}$ & $\begin{array}{l}-10.185 \\
(12.603)\end{array}$ & $\begin{array}{c}-7.473 \\
(12.651)\end{array}$ \\
\hline - wage_quotient & $\begin{array}{l}-3.092 \\
(7.340)\end{array}$ & $\begin{array}{l}-4.162 \\
(7.601)\end{array}$ & $\begin{array}{l}-4.268 \\
(7.770)\end{array}$ & $\begin{array}{l}-3.860 \\
(7.886)\end{array}$ & $\begin{array}{l}-4.937 \\
(8.085)\end{array}$ & $\begin{array}{l}-5.455 \\
(8.352)\end{array}$ \\
\hline - union_member & $\begin{array}{l}-0.156 \\
(1.208)\end{array}$ & $\begin{array}{l}-0.054 \\
(1.271)\end{array}$ & $\begin{array}{l}-0.070 \\
(1.157)\end{array}$ & $\begin{array}{c}0.293 \\
(0.863)\end{array}$ & $\begin{array}{c}0.385 \\
(0.842)\end{array}$ & $\begin{array}{c}0.293 \\
(0.754)\end{array}$ \\
\hline - log_population & $\begin{array}{c}\text { 81.347** } \\
(34.450)\end{array}$ & $\begin{array}{l}\text { 70.142*** } \\
\text { (33.012) }\end{array}$ & $\begin{array}{l}\text { 62.131* } \\
(31.108)\end{array}$ & $\begin{array}{l}\text { 118.945**** } \\
(42.221)\end{array}$ & $\begin{array}{c}102.540 * * \\
(40.358)\end{array}$ & $\begin{array}{l}\text { 92.456** } \\
(38.998)\end{array}$ \\
\hline \multicolumn{7}{|l|}{ CRIME CONTROLS } \\
\hline - log_violent_crimes_pc & & $\begin{array}{l}-8.275^{* * * *} \\
(3.013)\end{array}$ & $\begin{array}{c}-7.412 * * \\
(3.081)\end{array}$ & & $\begin{array}{c}-9.341 * * \\
(3.843)\end{array}$ & $\begin{array}{c}-7.834 * * \\
(3.834)\end{array}$ \\
\hline -log_property_crimes_pc & & $\begin{array}{l}-4.667 \\
(6.433)\end{array}$ & $\begin{array}{l}-7.556 \\
(6.254)\end{array}$ & & $\begin{array}{l}-7.192 \\
(7.395)\end{array}$ & $\begin{array}{l}-10.513 \\
(7.347)\end{array}$ \\
\hline \multicolumn{7}{|c|}{ PUBLIC SECTOR CONTROLS } \\
\hline - taxes_pc & & & $\begin{array}{c}-1.895 * * * \\
(0.460)\end{array}$ & & & $\begin{array}{c}-1.879 * * * \\
(0.469)\end{array}$ \\
\hline - political_balance & & & $\begin{array}{c}0.654 \\
(0.445)\end{array}$ & & & $\begin{array}{c}0.528 \\
(0.430)\end{array}$ \\
\hline Observations & 606 & 606 & 592 & 538 & 538 & 526 \\
\hline R-squared & 0.587 & 0.605 & 0.623 & 0.605 & 0.624 & 0.640 \\
\hline Number of states & 49 & 49 & 48 & 49 & 49 & 48 \\
\hline
\end{tabular}


Table 5. ATF/Laws. Panel data estimations with state and time fixed effects, 1997-2010 (II).

\begin{tabular}{|c|c|c|c|c|}
\hline & $(1)$ & $(2)$ & (3) & $(4)$ \\
\hline \multicolumn{5}{|l|}{ REGULATORY VARIABLES } \\
\hline - ATF_waitperiod_l & $\begin{array}{c}-0.309 \\
(1.777)\end{array}$ & & & \\
\hline - ATF_statelicense & & $\begin{array}{c}-\mathbf{0 . 8 0 7} * * \\
(0.317)\end{array}$ & & \\
\hline - ATF_preemption & & & $\begin{array}{c}3.194 \\
(2.265)\end{array}$ & \\
\hline - ATF_interstate & & & & $\begin{array}{c}-0.296 \\
(0.802)\end{array}$ \\
\hline \multicolumn{5}{|l|}{ ECONOMIC CONTROLS } \\
\hline - log_num_firms & $\begin{array}{c}3.718 \\
(10.596)\end{array}$ & $\begin{array}{l}-2.107 \\
(9.266)\end{array}$ & $\begin{array}{c}4.944 \\
(10.255)\end{array}$ & $\begin{array}{c}2.378 \\
(10.869)\end{array}$ \\
\hline - wage_quotient & $\begin{array}{l}-3.024 \\
(6.830)\end{array}$ & $\begin{array}{l}-2.503 \\
(6.154)\end{array}$ & $\begin{array}{l}-2.470 \\
(6.583)\end{array}$ & $\begin{array}{l}-3.780 \\
(8.133)\end{array}$ \\
\hline - union_member & $\begin{array}{c}0.529 \\
(1.014)\end{array}$ & $\begin{array}{c}0.117 \\
(0.871)\end{array}$ & $\begin{array}{c}0.504 \\
(1.003)\end{array}$ & $\begin{array}{c}0.230 \\
(1.318)\end{array}$ \\
\hline - log_population & $\begin{array}{l}44.930 * \\
(26.154)\end{array}$ & $\begin{array}{l}50.968 * \\
(25.506)\end{array}$ & $\begin{array}{l}45.399 * \\
(26.653)\end{array}$ & $\begin{array}{l}54.569 * \\
(28.946)\end{array}$ \\
\hline \multicolumn{5}{|l|}{ CRIME CONTROLS } \\
\hline - log_violent_crimes_pc & $\begin{array}{c}-4.845^{*} \\
(2.611)\end{array}$ & $\begin{array}{l}-5.245^{*} \\
(2.621)\end{array}$ & $\begin{array}{l}-5.165^{*} \\
(2.644)\end{array}$ & $\begin{array}{c}-6.083 * * \\
(2.962)\end{array}$ \\
\hline - log_property_crimes_pc & $\begin{array}{l}-5.644 \\
(5.762)\end{array}$ & $\begin{array}{l}-5.431 \\
(5.494)\end{array}$ & $\begin{array}{c}-6.642 \\
(5.507)\end{array}$ & $\begin{array}{c}-6.812 \\
(6.067)\end{array}$ \\
\hline \multicolumn{5}{|l|}{ PUBLIC SECTOR CONTROLS } \\
\hline - taxes_pc & $\begin{array}{c}-1.996 * * * \\
(0.540)\end{array}$ & $\begin{array}{c}-2.037 * * * \\
(0.532)\end{array}$ & $\begin{array}{c}-2.044 * * * \\
(0.557)\end{array}$ & $\begin{array}{c}-2.007 * * * \\
(0.559)\end{array}$ \\
\hline -political_balance & $\begin{array}{c}0.534 \\
(0.380)\end{array}$ & $\begin{array}{l}\text { 0.729* } \\
(\mathbf{0 . 3 8 5})\end{array}$ & $\begin{array}{c}0.653 \\
(0.392)\end{array}$ & $\begin{array}{c}0.575 \\
(0.404)\end{array}$ \\
\hline Observations & 658 & 662 & 658 & 622 \\
\hline R-squared & 0.590 & 0.611 & 0.596 & 0.606 \\
\hline Number of states & 48 & 48 & 48 & 48 \\
\hline
\end{tabular}

Note: See Table 4. 
Table 6. B/L Data. Panel data estimations with state and time fixed effects, 2006-2010 (I).

\begin{tabular}{|c|c|c|c|c|}
\hline & (1) & $(2)$ & (3) & $(4)$ \\
\hline \multicolumn{5}{|l|}{ REGULATORY VARIABLES } \\
\hline \multirow[t]{2}{*}{ - B/L_trafficking } & $-0.982 * * *$ & $-0.848 * *$ & $-0.980 * *$ & $-1.004 * *$ \\
\hline & (0.357) & $(\mathbf{0 . 3 7 0})$ & $(\mathbf{0 . 3 6 7 )}$ & (0.377) \\
\hline \multirow[t]{2}{*}{ - B/L_checks } & -0.569 & -0.805 & -1.020 & -0.989 \\
\hline & $(1.916)$ & $(1.598)$ & $(1.783)$ & $(1.821)$ \\
\hline \multirow[t]{2}{*}{ - B/L_childsafe } & 0.536 & $0.801 *$ & 0.583 & 0.575 \\
\hline & $(0.478)$ & $(0.444)$ & $(0.400)$ & $(0.386)$ \\
\hline \multirow{2}{*}{ - B/L_publicplace } & -0.415 & 0.093 & -0.036 & -0.088 \\
\hline & $(0.578)$ & $(0.527)$ & $(0.523)$ & $(0.523)$ \\
\hline \multicolumn{5}{|l|}{ ECONOMIC CONTROLS } \\
\hline \multirow[t]{2}{*}{ - log_num_firms } & & -22.198 & -18.977 & -18.508 \\
\hline & & $(22.225)$ & $(21.389)$ & $(21.709)$ \\
\hline \multirow[t]{2}{*}{ - wage_quotient } & & -23.208 & -26.266 & $-27.208 *$ \\
\hline & & $(18.079)$ & $(15.782)$ & (16.058) \\
\hline \multirow[t]{2}{*}{ - union_member } & & -2.012 & -1.528 & -1.122 \\
\hline & & $(2.136)$ & $(1.943)$ & $(2.040)$ \\
\hline \multirow[t]{2}{*}{ - log_population } & & $180.929 * *$ & $158.363 * *$ & $156.223 *$ \\
\hline & & $(72.523)$ & $(75.980)$ & $(81.692)$ \\
\hline \multicolumn{5}{|l|}{ CRIME CONTROLS } \\
\hline - log_violent_crimes_pc & & & $\begin{array}{c}-12.226 * * * \\
(4.126)\end{array}$ & $\begin{array}{c}-11.722 * * \\
(4.408)\end{array}$ \\
\hline - log_property_crimes_pc & & & $\begin{array}{c}0.967 \\
(9.592)\end{array}$ & $\begin{array}{c}-0.506 \\
(10.877)\end{array}$ \\
\hline \multicolumn{5}{|l|}{ PUBLIC SECTOR CONTROLS } \\
\hline - taxes_pc & & & & $\begin{array}{c}-0.507 \\
(0.363)\end{array}$ \\
\hline -political_balance & & & & $\begin{array}{c}-0.046 \\
(0.371)\end{array}$ \\
\hline Observations & 245 & 245 & 245 & 239 \\
\hline R-squared & 0.486 & 0.559 & 0.587 & 0.587 \\
\hline Number of states & 49 & 49 & 49 & 48 \\
\hline
\end{tabular}

Note: See Table 4. 
Table 7. B/L Data. Panel data estimations with state and time fixed effects, 2006-2010 (II).

\begin{tabular}{|c|c|c|c|c|}
\hline & (1) & (2) & (3) & (4) \\
\hline \multicolumn{5}{|l|}{ REGULATORY VARIABLES } \\
\hline - B/L_trafficking & $\begin{array}{c}-0.824 * * \\
(0.332)\end{array}$ & & & \\
\hline - B/L_checks & & $\begin{array}{l}-0.425 \\
(1.261)\end{array}$ & & \\
\hline - B/L_childsafe & & & $\begin{array}{c}0.250 \\
(0.382)\end{array}$ & \\
\hline - B/L_publicplace & & & & $\begin{array}{l}-0.146 \\
(0.535)\end{array}$ \\
\hline \multicolumn{5}{|l|}{ ECONOMIC CONTROLS } \\
\hline - log_num_firms & $\begin{array}{l}-11.926 \\
(21.675)\end{array}$ & $\begin{array}{c}-10.393 \\
(22.197)\end{array}$ & $\begin{array}{l}-13.649 \\
(22.411)\end{array}$ & $\begin{array}{c}-10.811 \\
(22.213)\end{array}$ \\
\hline - wage_quotient & $\begin{array}{l}-27.581 * \\
(15.566)\end{array}$ & $\begin{array}{l}-28.563^{*} \\
(15.564)\end{array}$ & $\begin{array}{l}-28.982^{*} \\
(15.481)\end{array}$ & $\begin{array}{l}-29.142 * \\
(15.600)\end{array}$ \\
\hline - union_member & $\begin{array}{l}-1.180 \\
(1.946)\end{array}$ & $\begin{array}{c}-1.401 \\
(1.991)\end{array}$ & $\begin{array}{l}-1.468 \\
(1.999)\end{array}$ & $\begin{array}{l}-1.175 \\
(2.110)\end{array}$ \\
\hline - log_population & $\begin{array}{c}147.149 * \\
(86.264)\end{array}$ & $\begin{array}{c}\text { 153.995* } \\
(87.068)\end{array}$ & $\begin{array}{c}160.763 * \\
(84.626)\end{array}$ & $\begin{array}{c}152.444 * \\
(84.664)\end{array}$ \\
\hline \multicolumn{5}{|l|}{ CRIME CONTROLS } \\
\hline - log_violent_crimes_pc & $\begin{array}{c}-12.108 * * * * \\
(4.313)\end{array}$ & $\begin{array}{c}-11.310 * * \\
(4.223)\end{array}$ & $\begin{array}{c}-10.766 * * \\
(4.234)\end{array}$ & $\begin{array}{c}-11.288 * * \\
(4.343)\end{array}$ \\
\hline - log_property_crimes_pc & $\begin{array}{c}-1.763 \\
(11.045)\end{array}$ & $\begin{array}{c}-1.972 \\
(11.088)\end{array}$ & $\begin{array}{c}-1.396 \\
(10.875)\end{array}$ & $\begin{array}{c}-1.860 \\
(11.097)\end{array}$ \\
\hline \multicolumn{5}{|l|}{ PUBLIC SECTOR CONTROLS } \\
\hline - taxes_pc & $\begin{array}{c}-0.542 \\
(0.373)\end{array}$ & $\begin{array}{l}-0.495 \\
(0.382)\end{array}$ & $\begin{array}{l}-0.470 \\
(0.382)\end{array}$ & $\begin{array}{l}-0.499 \\
(0.374)\end{array}$ \\
\hline -political_balance & $\begin{array}{c}0.022 \\
(0.424)\end{array}$ & $\begin{array}{l}-0.047 \\
(0.432)\end{array}$ & $\begin{array}{l}-0.083 \\
(0.402)\end{array}$ & $\begin{array}{l}-0.036 \\
(0.428)\end{array}$ \\
\hline Observations & 239 & 239 & 239 & 239 \\
\hline R-squared & 0.582 & 0.574 & 0.575 & 0.574 \\
\hline Number of states & 48 & 48 & 48 & 48 \\
\hline
\end{tabular}

Note: See Table 4. 
Table 8. V/H Data. Panel data estimations with state and time fixed effects (I).

\begin{tabular}{|c|c|c|c|c|c|}
\hline & $\begin{array}{c}(1) \\
1986-1999 \\
\end{array}$ & $\begin{array}{c}(2) \\
1986-1999 \\
\end{array}$ & $\begin{array}{c}(3) \\
1986-1999 \\
\end{array}$ & $\begin{array}{c}(4) \\
1986-1999 \\
\end{array}$ & $\begin{array}{c}(5) \\
1992-1999 \\
\end{array}$ \\
\hline \multicolumn{6}{|l|}{ REGULATORY } \\
\hline \multicolumn{6}{|l|}{ VARIABLES } \\
\hline \multirow{2}{*}{ - V/H_trafficking } & 0.158 & 0.159 & 0.154 & 0.153 & $0.231 * *$ \\
\hline & $(0.110)$ & $(0.110)$ & $(0.110)$ & $(0.111)$ & $(0.113)$ \\
\hline \multirow[t]{2}{*}{ - V/H_checks } & $-0.459 *$ & $-0.453 *$ & $-0.444 *$ & -0.468 & $-0.591 * *$ \\
\hline & $(0.261)$ & $(0.257)$ & $(0.264)$ & $(0.301)$ & $(0.234)$ \\
\hline \multirow[t]{2}{*}{ - V/H_childsafe } & 0.013 & 0.018 & 0.013 & 0.023 & $-0.448 * *$ \\
\hline & $(0.132)$ & $(0.132)$ & $(0.142)$ & $(0.141)$ & $(0.208)$ \\
\hline \multirow[t]{2}{*}{ - V/H_bans } & -0.292 & -0.285 & -0.315 & -0.319 & -0.129 \\
\hline & $(0.247)$ & $(0.237)$ & $(0.242)$ & $(0.250)$ & $(0.287)$ \\
\hline -V/H_sentencing & $\begin{array}{l}-0.327 \\
(1.050)\end{array}$ & $\begin{array}{l}-0.285 \\
(1.012)\end{array}$ & $\begin{array}{l}-0.434 \\
(0.966)\end{array}$ & $\begin{array}{l}-0.438 \\
(0.969)\end{array}$ & $\begin{array}{l}1.163 \\
(1.128)\end{array}$ \\
\hline \multicolumn{6}{|l|}{ ECONOMIC CONTROLS } \\
\hline - log_num_firms & & & & & $\begin{array}{l}-2.865 \\
(3.468)\end{array}$ \\
\hline - union_member & & $\begin{array}{l}-0.533 \\
(0.318)\end{array}$ & $\begin{array}{l}-0.511 \\
(0.319)\end{array}$ & $\begin{array}{l}-0.516 \\
(0.315)\end{array}$ & $\begin{array}{l}-0.288 \\
(0.392)\end{array}$ \\
\hline - log_population & & $\begin{array}{l}-0.546 \\
(2.865)\end{array}$ & $\begin{array}{l}-0.691 \\
(2.792)\end{array}$ & $\begin{array}{l}-0.628 \\
(2.801)\end{array}$ & $\begin{array}{l}-2.938 \\
(5.526)\end{array}$ \\
\hline \multicolumn{6}{|l|}{ CRIME CONTROLS } \\
\hline - log_violent_crimes_pc & & & $\begin{array}{l}-0.866 \\
(0.862)\end{array}$ & $\begin{array}{l}-0.943 \\
(0.871)\end{array}$ & $\begin{array}{c}0.200 \\
(1.135)\end{array}$ \\
\hline - log_property_crimes_pc & & & $\begin{array}{l}-0.387 \\
(1.782)\end{array}$ & $\begin{array}{l}-0.388 \\
(1.797)\end{array}$ & $\begin{array}{l}-2.595 \\
(2.899)\end{array}$ \\
\hline \multicolumn{6}{|l|}{$\begin{array}{l}\text { PUBLIC SECTOR } \\
\text { CONTROLS }\end{array}$} \\
\hline - taxes_pc & & & & & $\begin{array}{c}0.072 \\
(0.468)\end{array}$ \\
\hline -political_balance & & & & $\begin{array}{l}-0.048 \\
(0.100)\end{array}$ & $\begin{array}{l}-0.196 \\
(0.138)\end{array}$ \\
\hline Observations & 686 & 686 & 686 & 672 & 384 \\
\hline R-squared & 0.195 & 0.197 & 0.201 & 0.199 & 0.157 \\
\hline Number of states & 49 & 49 & 49 & 48 & 48 \\
\hline
\end{tabular}

Note: See Table 4. 
Table 9. V/H Data. Panel data estimations with state and time fixed effects, 1986-1999 (II).

\begin{tabular}{|c|c|c|c|c|c|}
\hline \multirow{2}{*}{\multicolumn{6}{|c|}{ REGULATORY VARIABLES }} \\
\hline & & & & & \\
\hline - V/H_trafficking & $\begin{array}{c}0.157 \\
(0.114)\end{array}$ & & & & \\
\hline - V/H_checks & & $\begin{array}{l}-0.529 * \\
(0.298)\end{array}$ & & & \\
\hline - V/H_childsafe & & & $\begin{array}{l}-0.120 \\
(0.151)\end{array}$ & & \\
\hline - V/H_bans & & & & $\begin{array}{l}-0.451 \\
(0.281)\end{array}$ & \\
\hline - V/H_sentencing & & & & & $\begin{array}{l}-1.030 \\
(0.755)\end{array}$ \\
\hline ECONOMIC CONTROLS & & & & & \\
\hline - union_member & $\begin{array}{l}-\mathbf{- 0 . 7 0 6 *} \\
(0.388)\end{array}$ & $\begin{array}{l}-0.639 \\
(0.392)\end{array}$ & $\begin{array}{l}-0.703 \\
(0.440)\end{array}$ & $\begin{array}{l}-0.670 \\
(0.447)\end{array}$ & $\begin{array}{l}-0.609 \\
(0.363)\end{array}$ \\
\hline - log_population & $\begin{array}{l}-0.880 \\
(2.707)\end{array}$ & $\begin{array}{c}0.261 \\
(2.869)\end{array}$ & $\begin{array}{l}-0.114 \\
(2.670)\end{array}$ & $\begin{array}{l}-0.824 \\
(2.694)\end{array}$ & $\begin{array}{l}-0.950 \\
(2.700)\end{array}$ \\
\hline CRIME CONTROLS & & & & & \\
\hline - log_violent_crimes_pc & $\begin{array}{l}-0.708 \\
(0.820)\end{array}$ & $\begin{array}{l}-0.745 \\
(0.837)\end{array}$ & $\begin{array}{l}-0.604 \\
(0.860)\end{array}$ & $\begin{array}{l}-0.810 \\
(0.833)\end{array}$ & $\begin{array}{l}-0.936 \\
(0.829)\end{array}$ \\
\hline - log_property_crimes_pc & $\begin{array}{c}0.005 \\
(1.692)\end{array}$ & $\begin{array}{l}-0.272 \\
(1.698)\end{array}$ & $\begin{array}{l}-0.290 \\
(1.825)\end{array}$ & $\begin{array}{l}-0.064 \\
(1.705)\end{array}$ & $\begin{array}{l}-0.195 \\
(1.685)\end{array}$ \\
\hline $\begin{array}{l}\text { PUBLIC SECTOR CONTROLS } \\
\text { - political_balance }\end{array}$ & $\begin{array}{l}-0.048 \\
(0.105)\end{array}$ & $\begin{array}{l}-0.053 \\
(0.100)\end{array}$ & $\begin{array}{l}-0.060 \\
(0.099)\end{array}$ & $\begin{array}{l}-0.078 \\
(0.103)\end{array}$ & $\begin{array}{l}-0.079 \\
(0.102)\end{array}$ \\
\hline Observations & 672 & 672 & 672 & 672 & 672 \\
\hline R-squared & 0.177 & 0.189 & 0.175 & 0.177 & 0.179 \\
\hline Number of states & 48 & 48 & 48 & 48 & 48 \\
\hline
\end{tabular}

Note: See Table 4. 
Table 10. Summary of results.

\begin{tabular}{|c|c|c|c|c|c|c|}
\hline \multirow[b]{2}{*}{ Law variables entry $=>$} & \multicolumn{2}{|c|}{ ATF/Laws (1997-2010) } & \multicolumn{2}{|c|}{$\mathrm{B} / \mathrm{L}(2006-2010)$} & \multicolumn{2}{|c|}{ V/H (1986-1999) } \\
\hline & $\begin{array}{c}\text { Table } 4 \\
\text { simultaneous } \\
(\text { col. } 3)\end{array}$ & $\begin{array}{l}\text { Table } 5 \\
\text { one by } \\
\text { one }\end{array}$ & $\begin{array}{c}\text { Table } 6 \\
\text { simultaneous } \\
(\text { col. } 4)\end{array}$ & $\begin{array}{c}\text { Table } 7 \\
\text { one by } \\
\text { one }\end{array}$ & $\begin{array}{c}\text { Table } 8 \\
\text { simultaneous } \\
(\text { col. } 4)\end{array}$ & $\begin{array}{c}\text { Table } 9 \\
\text { one by } \\
\text { one }\end{array}$ \\
\hline ATF_waitperiod_l & $-\checkmark$ & $-\checkmark$ & & & & \\
\hline ATF_statelicense & $-\checkmark$ & $-\checkmark$ & & & & \\
\hline$A T F \_p r e e m p t$ & $+\checkmark$ & $+\checkmark$ & & & & \\
\hline ATF_interstate & {$[-]$} & {$[-]$} & & & & \\
\hline B/L_trafficking & & & $-\checkmark$ & $-\checkmark$ & & \\
\hline B/L_checks & & & $-\checkmark$ & $-\checkmark$ & & \\
\hline$B / L \_c h i l d s a f e$ & & & {$[+]$} & {$[+]$} & & \\
\hline B/L_publicplace & & & $-\checkmark$ & $-\checkmark$ & & \\
\hline V/H_trafficking & & & & & + & + \\
\hline V/H_checks & & & & & $-\sqrt{ } *$ & $-\checkmark$ \\
\hline V/H_childsafe & & & & & {$[+]$} & {$[-]$} \\
\hline V/H_bans & & & & & $-\checkmark$ & $-\checkmark$ \\
\hline$V / H \_$sentencing & & & & & $-\checkmark$ & $-\checkmark$ \\
\hline log_num_firms & - & $+\checkmark$ & - & - & $\mathrm{n} / \mathrm{a}$ & $\mathrm{n} / \mathrm{a}$ \\
\hline wage_quotient & $-\checkmark$ & $-\checkmark$ & $-\checkmark$ & $-\checkmark$ & $\mathrm{n} / \mathrm{a}$ & $\mathrm{n} / \mathrm{a}$ \\
\hline union_member & $-\checkmark$ & + & $-\checkmark$ & $-\checkmark$ & $-\checkmark$ & $-\checkmark$ \\
\hline log_population & $+\checkmark$ & $+\checkmark$ & $+\checkmark$ & $+\checkmark$ & - & - \\
\hline log_violent_crimes_pc & $-\checkmark$ & $-\checkmark$ & $-\checkmark$ & $-\checkmark$ & $-\checkmark$ & $-\checkmark$ \\
\hline log_property_crimes_pc & $-\checkmark$ & $-\checkmark$ & $-\checkmark$ & $-\checkmark$ & $-\checkmark$ & $-\checkmark$ \\
\hline taxes_pc & $-\checkmark$ & $-\checkmark$ & $-\checkmark$ & $-\checkmark$ & $\mathrm{n} / \mathrm{a}$ & $\mathrm{n} / \mathrm{a}$ \\
\hline political_balance & {$[+]$} & {$[+]$} & {$[-]$} & {$[-]$} & {$[-]$} & {$[-]$} \\
\hline
\end{tabular}

Notes: Summary of results from the linear estimates (Tables 4 to 9 ). + /- indicates the sign of the estimated coeffient. A checkmark indicates a coefficient in the expected direction. A cell without checkmark indicates that the sign went in the unexpected direction. [...] indicates that we had no expectation on the direction of the sign (nor expected statistical significance). The sign inside [...] is the observed sign from the estimations. " $\mathrm{n} / \mathrm{a}$ " indicates not used as data was not available. Shaded cells indicate statistically significant estimates. ${ }^{*}$ The $V / H \_c h e c k s$ coefficient is not statistically significant in col. 4 of Table 9 but it is statistically significant in cols. 1, 2, 3, and 5 of that table, wherefore we shaded this cell here as well. 


\section{References}

Akerlof, G.A., R.E. Kranton. 2000. "Economics and Identity." The Quarterly Journal of Economics. Vol. 115, No. 3, pp. 715-753.

Arauzo-Carod, J.M., D. Liviano-Solis, M. Manjón-Antolín. 2010. "Empirical Studies in Industrial Location: An Assessment of Their Methods and Results”. Journal of Regional Science. Vol. 50, No. 3, pp. 685-711.

Arellano, M., S. Bond. 1991. "Some Tests of Specification for Panel Data: Monte Carlo Evidence and an Application to Employment Equations." Review of Economic Studies. Vol 58, No. 2, pp. 277-297.

[ATF1] Bureau of Alcohol, Tobacco, Firearms, and Explosives. Various years. Annual Firearms Manufacturing and Export Report. (AFMER.) Washington, D.C.: U.S. Department of Homeland Security. Bureau of Alcohol, Tobacco, Firearms, and Explosives.

[ATF2] Bureau of Alcohol, Tobacco, Firearms, and Explosives. Various years. State Laws and Published Ordinances - Firearms. Washington, D.C.: U.S. Department of Homeland Security. Bureau of Alcohol, Tobacco, Firearms, and Explosives.

[Brady] Brady Campaign to Prevent Violence. 2013. "2013 State Scorecard." See <http://bradycampaign.org/?q=2013-state-scorecard > [accessed 12 January 2014].

Brauer, J. 2013. "The US Firearms Industry: Production and Supply." Working Paper 14. Geneva: Small Arms Survey.

Briggs, J.T. and A. Tabarrok. 2014. "Firearms and Suicides in U.S. States." International Review of Law and Economics. Vol. 37 (March), pp. 180188.

Cook, P.J., J. Ludwig. 2000. Gun Violence: The Real Costs. Oxford: Oxford University Press.

Cook, P.J. and K.A. Goss. 2014. The Gun Debate: What Everyone Needs to Know. New York: Oxford University Press.

Depetris-Chauvin, E. 2015. "Fear of Obama: An Empirical Study of the Demand for Guns and the U.S. 2008 Presidential Election." Journal of Public Economics. No. 130, pp. 66-79.

DeSimone, J., S. Markowitz, and J. Xu. 2013. "Child Access Prevention Laws and Nonfatal Gun Injuries." Southern Economic Journal. Vol. 80, No. 1, 
pp. 5-25.

Dube, A., O. Dube, and O. García-Ponce. 2013. "Cross-Border Spillover: U.S. Gun Laws and Violence in Mexico." American Political Science Review. Vol. 107, No. 3, pp. 397-417.

Fleegler, E.W., L.K. Lee, M.C. Monuteaux, D. Hemenway, and R. Mannix. 2013. "Firearm Legislation and Firearm-Related Fatalities in the United States." JAMA Internal Med. 6 March 2013.

Ghosh, P. 2014. "Southern Exposure: As Gun Sales Surge, Northeast Manufacturers Fleeing for Dixie." International Business Times. 10 January 2014. <http://www.ibtimes.com/southern-exposure-gun-salessurge-northeast-manufacturers-fleeing-dixie-1533842> [accessed 13 January 2014].

Habakkuk, H.J. 1962. American and British Technology in the Nineteenth Century: The Search for Labour-Saving Inventions. Cambridge, UK: Cambridge University Press.

Hall, P, S Markowski, J Brauer. 2008. "The U.S. Small Arms Industry: Profit, Proliferation, Performance." Asteriskos: Journal of International and Peace Studies. Nos. 5/6, pp. 41-62.

Hemenway, D. 2004. Private Guns, Public Health. Ann Arbor, MI: The University of Michigan Press.

Hounshell, D.A. 1984. From the American System to Mass Production, 18001932. Baltimore, MD and London: The Johns Hopkins University Press.

Howard, R. 1979. "Interchangeable Parts Reexamined: The Private Sector of the American Arms Industry on the Eve of the Civil War." Technology and Culture. Vol. 19 (October), pp. 633-649.

Kahane, L.H. 2013. "Understanding the Interstate Export of Crime Guns: A Gravity Model Approach." Contemporary Economic Policy. Vol. 31, No. 3, pp. 618-634.

Knight, B. 2013. "State Gun Policy and Cross-State Externalities: Evidence from Crime Gun Tracing." American Economic Journal: Economic Policy. Vol. 5, No. 4, pp. 200-229.

Krouse, W.J. 2013. "Gun Control Proposals in the 113th Congress: Universal Background Checks, Gun Trafficking, and Military Style Firearms." Report 42987 (7 June 2013). Washington, D.C.: Congressional Research Service. 
Lanza, S.P. 2013. "Targeting Gun Violence: Can We Reduce Gun Deaths and Not Lose Jobs?" University of Connecticut. The Connecticut Economy. Summer 2013, pp. 5-7.

[MAIG] Majors Against Illegal Guns. 2010. "Trace the Guns: The Link between Gun Laws and Interstate Gun Trafficking." September 2010.

McDougal, T., D.A. Shirk, R. Muggah, and J.H. Patterson. 2014. "The Way of the Gun: Estimating Firearms Traffic Across the U.S.-Mexico Border." Journal of Economic Geography. doi:10.1093/jeg/lbu021.

Rosenberg, N. 1963. "Technological Change in the Machine Tool Industry, 18401910." Journal of Economic History. Vol. 23, No. 4, pp. 414-443.

Smith Merritt, R. 1973. "John H. Hall, Simeon North, and the Milling Machine: The Nature of Innovation among Antebellum Arms Makers." Technology and Culture. Vol. 14, pp. 573-591.

Taylor, B. and J. Li. 2015. "Do Fewer Guns Lead to Less Crime? Evidence from Australia." International Review of Law and Economics. Vol. 42 (June), pp. 72-78.

Vernick, J.S. and L.M. Hepburn. 2003. "State and Federal Gun Laws: Trends for 1970-99," pp. 345-410 in J. Ludwig and P.J. Cook, eds. Evaluating Gun Policy: Effects on Crime and Violence. Washington, D.C.: The Brookings Institution.

Webster, D., C. Kercher Crifasi and J.S. Vernick. 2014. "Effects of the Repeal of Missouri's Handgun Purchaser Licensing Law on Homicides." Journal of Urban Health, March.

Wooldridge, J.M. 2016. Introductory Econometrics: A Modern Approach. 6th ed. Boston: Cengage. 